Best of all, wastewater disinfection occurred in the anode zone with an electrodialysis duration of 20 minutes.

After ultrasonic wastewater treatment at an operating frequency of $840 \mathrm{kHz}$, power of $91 \mathrm{~W}$ and intensity of $0.7 \mathrm{~W} / \mathrm{cm}^{2}$ for 12 minutes the degree of water purification according to physico-chemical indicators is in the range of 55-79\%, and the degree of disinfection is $98 \%$.

Changes in physicochemical parameters after treatment of wastewater by magnetic field with a magnetic induction intensity of $75 \mathrm{mT}$ for 10 minutes consisted in $72 \%$ COD reduction. The reduction of other related indicators is in the range of $30-50 \%$, and the degree of destruction of microorganisms is $87 \%$.

The treatment by low-frequency radiation at a frequency of $100 \mathrm{kHz}$ and voltage amplitude of $5 \mathrm{~V}$ for 17 minutes resulted in the decrease of organic substances content to $60 \%$, minerals to $73 \%$ and the degree of disinfection of $76 \%$.

The treatment by ultrahigh frequency radiation with a frequency of $60 \mathrm{GHz}$ and wavelength of $270 \mathrm{~mm}$ for 24 minutes resulted in the decrease of suspended solids content, chlorides and sulfate in the range of 72-80\% as well as the degree of disinfection of $64 \%$.

Thus, the use of physico-chemical methods for wastewater treatment allows to obtain a high antimicrobial effect and a significant reduction in pollutants, which leads to an improvement in sanitary and epidemiological indicators of wastewater quality.

Keywords: wastewater, electrodialysis, ultrasound, magnetic field, ultrahigh frequency radiation, low-frequency radiation. 


\section{QUALITY MANAGEMENT OF VEGETABLES WITH THE APPLICATION OF NANO PREPARATIONS}

O. ULIANYCH, Doctor of Agricultural Sciences

N. OSOKINA, Doctor of Agricultural Sciences

K. KOSTETSKA, PhD of Agricultural Sciences

O. KUHNYUK, PhD of Agricultural Sciences

Uman National University of Horticulture

K. SHEVCHUK

\section{LLC «Nunems Ukraine»}

Наведено результати чотирирічних досліджень з вивчення умов підвищення урожайності шпинату за внесення абсорбентів із застосуванням технологічних прийомів для підвищення його продуктивності. Встановлено, щңо абсорбенти не викликали негативних змін у рослинах і позитивно впливали на якість врожаю шпинату городнього та сприяли підвищенню важливих показників хімічного складу. Вищий вміст сухої розчинної речовини у сортів Красень Полісся і Малахіт спостерігався за застосування абсорбентів фірми Максимарин у формі гранул і гелю - 8,1-8,9\%. Вищим вмістом иукрів відрізнялися рослини, вирощені із застосуванням абсорбентів фірми Максимарин у формі гранул і гелю - 2,6-2,9\% та гранул з калієм фірми Еко2,7-2,8\%. За вмістом вітаміну C переважали рослини, вирощені із застосуванням абсорбентів фірми Максимарин у формі гранул і гелю - 56$62 \%$ та гранул з калієм фірми Еко - 58-64\%.

Ключові слова: шпинат, сорт, абсорбент, товарна продукиія, врожайність, показники якості. 
Introduction. High yield of spinach (Spinacia) requires optimal growth conditions in arid conditions. In the scientific literature, it is recommended to use absorbents to promote growth in arid conditions. Absorbents are natural or synthetic compounds that are used to soil to initiate changes in processes of their living abilities to improve the quality of plant material, increase a yield, facilitate harvesting and storage. The use of absorbents leads to changes in metabolism similar to those that occur under the influence of external conditions.

That is, absorbents are not nutrients, but factors for ensuring plant growth and development. Absorbents activate the basic life processes in the plants. Under their influence accelerates the growth of green mass and the root system, and therefore more actively used water and dissolved in it soil substances and mineral fertilizers, increase the protective properties of plants, their resistance to diseases, high and low temperatures, drought. The yield is increasing, and the quality of the vegetables is improving accordingly. To use of the absorbents allows to realize potential of the plants which inherent by nature and breeding [1-5].

Analysis of recent studies and publications. Now the plant is most grown in China and the USA, why in America, three quarters of the spinach crop goes on sale fresh. Spinach consumption in the United States almost returned to the mid-20th century. In the developed special diets for astronauts, spinach is always present. Today, young spinach - the so-called baby spinach with tender leaves up to $5 \mathrm{~cm}$ long - is gaining market positions [6]. Spinach is a culture of the temperate zone. It grows better and grows the leaf part at a temperature of $10-18^{\circ} \mathrm{C}$, and at temperatures above $20^{\circ} \mathrm{C}$ quickly forms peduncles. On long daylight, high temperatures and lack of moisture spinach plants shoot quickly $[7,8]$.

The widespread introduction of vegetable spinach into agricultural production is hampered by the lack of enough choices of varieties and scientifically grounded technology of the organic cultivation in the Right-Bank Forest Steppe of Ukraine. For this purpose, it is necessary to extensively study the agro biological features of the plants, to breed new high-yielding varieties, to improve the technology of the organic cultivation, to establish the conditions for obtaining high productivity, prolongation 
of the fresh consumption, since the existing intensive technology does not allow to obtain environmentally safe products $[9,10]$.

The population has increased interest in consuming exclusively natural food as a way of improving the quality of life $[5,10]$. Now both professionals and consumers talk about natural products with special properties [9]. Some authors related their research to technology of the spinach growing last years. However, the widespread introduction of spinach into production is hampered by the lack of zonal sciencebased cultivation technology. The relevancy of existing issues leads to the conduct and justification of the scientific research $[1,11]$.

The purpose and objectives of research. The purpose of the research was to study the increase of yield by using absorbents and develop technological techniques for improving productivity.

Materials and methods. The study of influence of hydrogel firms Maximarin used in the form of tablets, gel, granules). For spinach cultivation, preparations were used in the following forms: MaxiMarin gel-like, MaxiMarin tableted, MaxiMarin granular, and also potassium (K), medium pallets, bentolite on grow and yield of cultivars spinach: Malachite, Krasen Polissia.

The research was carried out in 2015-2018 at experimental field of the Department of Vegetable Growing of Uman National University of Horticulture in accordance with generally accepted methods $[12,13]$. The soil of experimental field is black, puddle, heavy loam with a well developed humus horizon (2,9\% of humus) in the deep of $40-45 \mathrm{~cm}$. The total area: for experiment $500 \mathrm{~m}^{2}$, for plot $-50 \mathrm{~m}^{2}$; for sampling $-5 \mathrm{~m}^{2}$. The plots were arranged in a systematic order with a four replication. The number of leaves per plant (pcs) was determined by the method of calculation, the area of the leaf blade by a calculated (linear) method, using parameters of the length and width of the leaf by the formula 1 :

$$
S_{n}=0.74 \times a \times b
$$

where: $\mathrm{Sn}$ - the area of one leaf, $\mathrm{cm}^{2}$;

a - the largest leaf width, cm;

$\mathrm{b}$ - leaf length, $\mathrm{cm}$; 
0,74 is the coefficient that reflects the configuration of the leaf.

The data were statistically analyzed using Analysis of variance Microsoft Office Excel.

Results and discussion. Spinach's leaf is the main product of consumption and is crucial for evaluating its quality, as for every green plant, which determines its edible properties during consumption. The number of leaves in the socket is important for spinach as a green plant. The definition of this indicator in the experiment showed that in 2015 the number of leaves is in the range of 17-23 leaves per plant (Fig. 1).

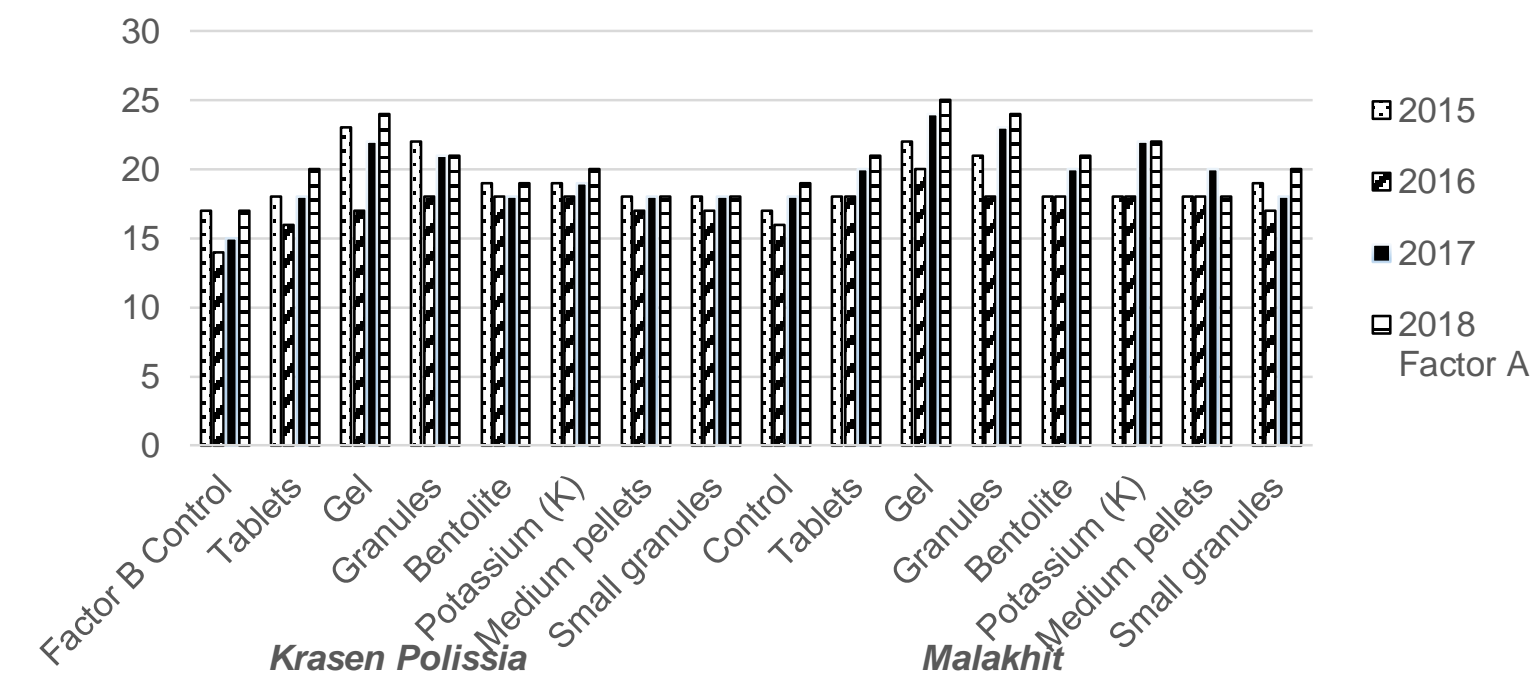

\section{Figure 1. The number of leaves in spinach and in the phase of technical maturity, depending on the action of the absorbents, pcs/plant}

Plants that grew with applying of the absorbents in the form of gel and granules were distinguished by a larger number of leaves - 22-23 leaves per plant. In 2016, the number of leaves was lower due to the worse growing conditions and ranged from 14 to 20 leaves per plant. In 2017 and 2018, a higher number of leaves were received for the applying of gel and granules - 21-25 leaves per plant, which significantly exceeded the control by 6-9 leaves per plant (Fig. 1).

The number of the leaves during research years was 16 leaves per plant due to the variety "Krasen Polissya" without the applying of the absorbent and 18 leaves per plant due to the variety "Malachit". Growing of spinach with using of various forms of absorbents contributed to the increase number of the leaves and was 18 leaves per 
plant due to variety "Krasen Polissia" and was 19 leaves per plant due to variety "Malachit". The applying of the gel increase the number of leaves up to 22 due to variety "Krasen Polissya" and increase up to 23 due to variety "Malachit". Using of the granules caused a slightly lower effect, but the excess of control was sufficiently high and amounted to 5-6 pcs.

The number of leaves in the socket is important for spinach as a green plant. The definition of this indicator in the experiment showed that in 2015 the number of leaves is in the range from 17 to 23 leaves per plant. The higher number of leaves had plants which were grown in conditions of using of absorbents in the form of gel and granules. Their range was from 22 to 23 leaves per plant. In 2016, the number of leaves was the lowest due to the worse growing conditions and ranged from 14 to 20 leaves per plant. In 2017 and 2018, higher number of leaves (21-25 leaves per plant) were obtained due to the using of absorbents in the form of gel and granules, which significantly exceeded the control by 6-9 leaves per plant.

During research years current indicator was 16 leaves per plant due to variety "Krasen Polissia" without absorbent (control) and 16 leaves per plant due to variety "Malachit". Growing of spinach with applying different absorbents stimulation of increasing number of leaves up to 18 leaves per plant due to use pellets and variety "Krasen Polissia" and up to 19 leaves per plant due to variety "Malachit" that were higher compere with control at 2-3 leaves per plant.

The applying of the absorbent in the form of gel increased the number of leaves up to 22 leaves per plant due to the variety "Krasen Polissya" and up to 23 leaves per plant due to the variety "Malachit". It was exceeding control at 6-7 leaves per plant.

The applying of the pellets caused a slightly lower effect, but the advantage to control was 5-6 leaves per plant. Use of ECO's products of different size and composition showed that the number of leaves in the prickly seeded spinach due to the variety "Krasen Polissya" in accordance with the form of applying corresponded to different indicators. Thus, the applying of potassium pellets contributed to the higher number of leaves compare to control (19-20 leaves per plant) which is higher than the control at 3-4 leaves per plant. 
Growing of spinach with using of various forms of absorbents contributed to the increase of leaf surface. For use of pellets was 108.9 sq. cm due to variety Krasen Polissya and 104.8 sq. $\mathrm{cm}$ due to the variety Malachit. Use of gel contributed to the increase of leaf surface up to 113,1 sq. $\mathrm{cm}$ due to the variety Krasen Polissya and 112.5 sq. $\mathrm{cm}$ due to the variety Malachit which were higher than the control at 6,9-7.

The use of ECO's products of different size and composition showed that leaf surface of variety Krasen Polissya in depend to form of product met different indicators. The leaf surface was in a range from 109,4 to 112,4 sq. $\mathrm{cm}$ due to use potassium granules and it was in a range from 110,8 to 108,5 sq. $\mathrm{cm}$ due to use medium sized granules.

An important indicator of the growth of prickly seeded spinach, which determined its value as a green plant, was the total leaves surface. This indicator was determined in the phase of industrial ripeness of the green (tables 1,2).

Table 1. The area of spinach leaves of Krasen Polissia variety depending on the absorbent, $10^{3} \mathrm{~m}^{2} / \mathrm{ha}$

\begin{tabular}{|l|c|c|c|c|c|}
\hline \multirow{2}{*}{ Absorbent } & \multicolumn{4}{c|}{ Year } & Average per \\
& \cline { 2 - 6 } & 2015 & 2016 & 2017 & $2018-2018$ \\
\hline Without making absorbent & 26,3 & 21,2 & 24,5 & 26,5 & 24,6 \\
\hline Tablet & 29,4 & 24,3 & 29,5 & 33,2 & 29,1 \\
\hline Gel & 39,4 & 27,3 & 37,6 & 40,1 & 36,1 \\
\hline Granule & 36,6 & 29,5 & 36,0 & 34,6 & 34,2 \\
\hline Granule with Concrete & 30,8 & 26,8 & 30,5 & 32,9 & 30,3 \\
\hline Granule with Potassium & 31,6 & 29,0 & 32,5 & 33,5 & 31,7 \\
\hline Medium pellets & 29,4 & 27,8 & 30,0 & 29,4 & 29,2 \\
\hline Small granules & 29,7 & 27,7 & 29,7 & 30,5 & 29,4 \\
\hline \multicolumn{1}{|c|}{$L S D_{05}$} & 1,58 & 1,33 & 1,56 & 1,63 & - \\
\hline
\end{tabular}

It is established that the leaves surface of prickly seeded spinach was 24,6 thousand sq. $\mathrm{m} / \mathrm{ha}$ due to the variety Malachit at the phase of technical maturity of the plant without use of absorbent. The higher indicator was from 34,2 to 38,1 thousand 
sq. $\mathrm{m} / \mathrm{ha}$ due to the use granules Maximarine and was higher than control from 9,6 to 13,5 thousand sq. $\mathrm{m} / \mathrm{ha}$.

Table 2. The area of spinach leaves of Malakhit variety depending on the absorbent, $10^{3} \mathrm{~m}^{2} / \mathrm{ha}$

\begin{tabular}{|l|c|c|c|c|c|}
\hline \multirow{2}{*}{ Absorbent } & \multicolumn{4}{c|}{ Year } & Average per \\
\cline { 2 - 6 } & 2015 & 2016 & 2017 & 2018 & -2018 \\
\hline Without making absorbent & 27,8 & 23,6 & 29,2 & 29,4 & 27,5 \\
\hline Tablet & 29,9 & 24,6 & 31,6 & 33,4 & 29,9 \\
\hline Gel & 37,9 & 30,1 & 41,1 & 43,2 & 38,1 \\
\hline Granule & 34,1 & 26,6 & 38,2 & 40,6 & 34,9 \\
\hline Granule with Concrete & 27,5 & 26,8 & 32,1 & 33,4 & 30,0 \\
\hline Granule with Potassium & 30,0 & 27,3 & 36,1 & 36,5 & 32,5 \\
\hline Medium pellets & 29,5 & 29,0 & 32,2 & 28,2 & 29,8 \\
\hline Small granules & 29,4 & 25,6 & 28,2 & 32,7 & 29,0 \\
\hline \multicolumn{1}{|c|}{$L S D_{05}$} & 1,54 & 1,34 & 1,70 & 1,73 & - \\
\hline
\end{tabular}

The applying potassium granules and medium granules of ECO showed positive result and leaves surface was from 29,2 to 32,5 thousand sq. $\mathrm{m} / \mathrm{ha}$ which was higher than the control at 4,6-7,9 thousand sq. $\mathrm{m} / \mathrm{ha}$.

Increasing the plants weight of prickly seeded spinach leads to an increase in yield, an indicator by which we determine the suitability of new elements of technology for growing the crops. The above data showed that the use of pellets helped to increase the weight of spinach plants in the phase of technical maturity up to $132 \mathrm{~g}$ due to the variety Krasen Polissya and up to $158 \mathrm{~g}$ due to the variety Malachit. Higher data was 180-192 due to applying gel and granules Maximarine and potassium granules "ECO" which was significantly higher than the control at 60-72 g $\left(\mathrm{LSD}_{05}(\right.$ Factor $\left.\mathrm{B})=17 \mathrm{~g}\right)$. The higher mass had plants of variety Malachit (171$178 \mathrm{~g}$ ) due to the applying gel and granules Maximarine and $150 \mathrm{~g}$ due to the potassium granules of ECO which significantly outweighed the control at 42-70 g.

It is established that the yield of spinach varied according to the influence of weather conditions during the years of researches and applied absorbents (Table 3). 
Table 3. The yield of spinach, depending on the absorbents, $t / h a$

\begin{tabular}{|c|c|c|c|c|c|c|c|}
\hline \multirow{2}{*}{$\begin{array}{c}\text { Variety } \\
\text { (Factor A) }\end{array}$} & \multirow{2}{*}{$\begin{array}{l}\text { Absorbent } \\
\text { (Factor B) }\end{array}$} & \multicolumn{4}{|c|}{ Year } & \multirow{2}{*}{$\begin{array}{l}\text { Average per } \\
2015-2018\end{array}$} & \multirow{2}{*}{$\begin{array}{c} \pm \text { to } \\
\text { Control }\end{array}$} \\
\hline & & 2015 & 2016 & 2017 & 2018 & & \\
\hline \multirow{8}{*}{$\begin{array}{l}\text { Krasen } \\
\text { Polissia }\end{array}$} & $\begin{array}{l}\text { Without making } \\
\text { absorbent }\end{array}$ & 17,1 & 12,9 & 15,4 & 16,8 & 15,6 & 0 \\
\hline & Tablet & 19,0 & 15,8 & 17,7 & 19,6 & 18,0 & $+2,4$ \\
\hline & Gel & 26,0 & 24,9 & 25,8 & 25,7 & 25,6 & $+10,0$ \\
\hline & Granule & 25,1 & 16,2 & 21,0 & 24,9 & 21,8 & $+6,2$ \\
\hline & $\begin{array}{l}\text { Granule with } \\
\text { Concrete }\end{array}$ & 18,5 & 15,8 & 19,6 & 18,5 & 18,1 & $+2,5$ \\
\hline & $\begin{array}{l}\text { Granule with } \\
\text { Potassium }\end{array}$ & 26,4 & 15,0 & 20,7 & 26,4 & 22,1 & $+6,5$ \\
\hline & Medium pellets & 14,8 & 25,9 & 20,4 & 15,1 & 19,0 & $+3,4$ \\
\hline & Small granules & 27,6 & 20,8 & 24,4 & 28,1 & 25,3 & $+9,7$ \\
\hline \multirow{8}{*}{ Malakhit } & $\begin{array}{l}\text { Without making } \\
\text { absorbent }\end{array}$ & 18,5 & 21,2 & 19,1 & 18,5 & 19,3 & $+3,7$ \\
\hline & Tablet & 20,5 & 18,0 & 19,3 & 20,5 & 19,6 & $+4,0$ \\
\hline & Gel & 28,5 & 21,9 & 30,2 & 28,5 & 27,3 & $+11,7$ \\
\hline & Granule & 22,4 & 23,9 & 24,7 & 26,4 & 24,4 & $+8,8$ \\
\hline & $\begin{array}{l}\text { Granule with } \\
\text { Concrete }\end{array}$ & 19,3 & 18,9 & 19,1 & 19,3 & 19,2 & $+3,6$ \\
\hline & $\begin{array}{l}\text { Granule with } \\
\text { Potassium }\end{array}$ & 22,6 & 21,7 & 24,7 & 23,6 & 23,2 & $+7,6$ \\
\hline & Medium pellets & 17,9 & 18,7 & 18,3 & 17,9 & 18,2 & $+2,6$ \\
\hline & Small granules & 16,3 & 16,4 & 21,4 & 22,3 & 19,1 & $+3,5$ \\
\hline \multirow[t]{3}{*}{$L S D_{05}$} & Factor A & 0,3 & 0,4 & 0,3 & 0,2 & \multirow{3}{*}{ - } & \multirow{3}{*}{ - } \\
\hline & Factor B & 0,7 & 0,9 & 0,8 & 0,7 & & \\
\hline & Interaction $A B$ & 0,9 & 1,4 & 1,3 & 1,6 & & \\
\hline
\end{tabular}

Significant increase of the yield of the spinach obtained due the applying of the gel. It was fixed 25,6 t/ha due to the variety Krasen Polissya $27,3 \mathrm{t} / \mathrm{ha}$ due to the variety Malachit which was additionally 10,0-11,7 ton/ha. The applying of the granules Maximarine helped increase yield up to 21,8-24,4 t/ha which was higher than the control at $6,2-8,8 \mathrm{t} / \mathrm{ha}$. The applying of the potassium granules ECO resulted in a lower yield of $22,1-23,2$ ton/ha and was higher than control at $6,5-7,6 \mathrm{t} / \mathrm{ha}$. A positive result was obtained with use of the medium and small granules due to the 
varieties of Malachit and Krasyn Polissya, and the yield increased by 2,6-9,7 t/ha. The applying of the bentonite granules allowed to restive from 2,5 to 3,6 tons per ha additionally.

The results of the dispersion analysis of the obtained data showed that factor B or absorbent and interaction of the factors had the highest influence on spinach yield (Fig. 2).

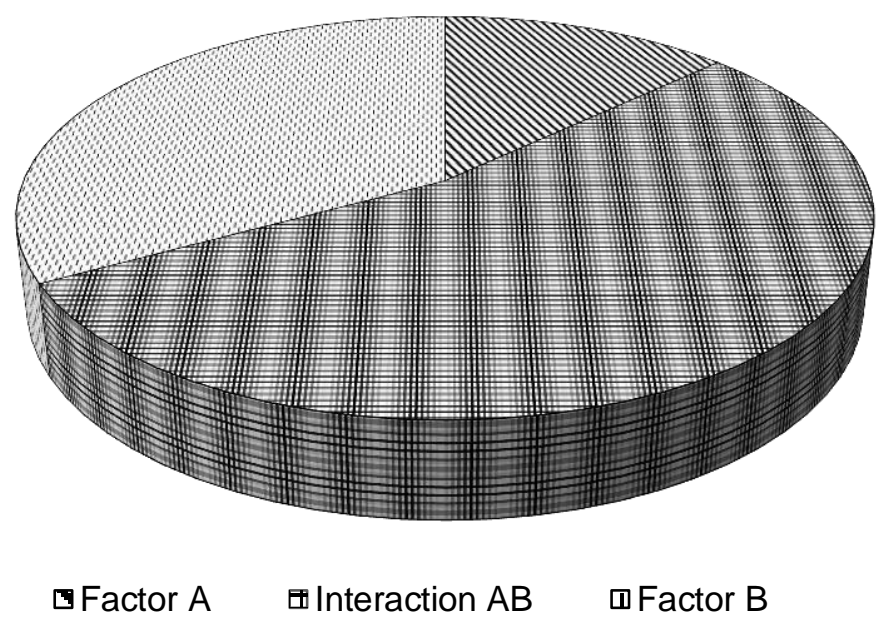

Fig. 2. Effect of factors on vegetable spinach yield depending on the absorbent input (average for 2015-2018), t/ha

The factor B or absorbent influenced on yield of spinach at $33 \%$. Higher influence had interaction of factors $(54 \%)$ due to the variety Malachit.

Absorbents didn't make negative changes in plants and positively influence on yield of spinach. They contributed to increasing important indicators of the chemical composition. Higher brix fixed at both varieties $(8,1-8,9 \%)$ due to use absorbents of Maximarine. Higher sugars content (2,6-2,9\%) revealed due to the use gel and granules of Maximarine. They were 2,7-2,8 \% due to use of the potassium granules ECO. On the content of the vitamin $\mathrm{C}$ predominant plants due to use absorbents of Maximarine in form of gel and granules $(56-62 \mathrm{mg} / 100 \mathrm{~g}$ ). It was $58-64 \mathrm{mg} / 100 \mathrm{~g}$ due to use potassium granules of ECO.

Scientific novelty and practical significance of the obtained results. In the conditions of the Forest-Steppe of Ukraine, experimental researches were conducted, 
which allowed to solve questions of the growing technology of the prickly seeded spinach and proved that the absorbents in arid conditions of the modern climate are effective for increasing the productivity of the spinach, and do not reduce production quality. It is impact established of the variety on the weight and height of the plant, the leaf-area surface and the total surface of the leaves, correlation dependences between the indices of plant growth and yield depending on the developed elements of the technology. The economic analysis of the elements of prickly seeded spinach growing technology was made.

Based on the conducted research, it is developed and recommended for agricultural producers of industrial, private and backyard sector to grow domestic early ripening varieties of spinach "Krasen Polissya" and "Malachit". Absorbents in arid conditions of modern climate contribute to increase of the prickly seeded spinach and receiving of high-quality production.

Conclusions. From the use of plant growth regulators during processing of spinach seeds, a higher profitability of the Malachit variety was obtained for the use of absorbents in the form of gel and granules - 83-102\%. The bioenergy efficiency ratio was more than unity, which indicates the efficiency of growing spinach 3,0-3,1.

\section{Література}

1. Улянич O. I., Алексейчук O. М. Застосування препаратів природнього походження для передпосівної обробки насіння шпинату городнього. Електронний збірник Наукові доповіді Національного університету біоресурсів $\quad$ п природокористування Украӥни. 2015 . № 5 (54) http://nd.nubip.edu.ua/2015_5/index.html.

2. Ульянич Е. И., Алексейчук О. М., Прудкий Р. И., Диденко И. А. Применение биопрепаратов для получения экологически безопасной продукции шпината огородного и сельдерея черешкового. Hayчные статьи Государственного аграрного университета Молдовы. 2015. Вып. 42. С. 225227. 
3. Bartolini S., Ducci E. Quality evaluation of local apple varieties: physicochemical and antioxidant proprieties at harvest and after cold storage. Agronomy Research. 2017. Vol. 15 (5). P. 1866-1877.

4. Darby K., Batte M.T., Ernst S., Roe B. Decomposing local: A conjoint analysis of locally produced foods. Am. J. Agr. Econ. 2008. 90 (2). P. 476-486.

5. Corbo M. R., Nobile M. A. D., Sinigaglia M. A novel approach for calculation shelf life of minimally processed vegetables. International Journal of Food Microbiology. 2006. № 106. P. 69-73.

6. Bosland P. W., Williams P. H. Pathogenicity of geographic isolates of Fusarium oxysporum from crucifers on a differential set of crucifer seedlings. Phytopathol. 1988. № 123. P. 63-68.

7. Mansfeld R. Vorlau figes verzeich nigland wirts chaftli chodergärtnerisch kultivierten Pflanzenarten. (Mit Ausschluss von Zierpflanzen). Die Kultur pflanze. Berlin, 1959. Beiheft 2.

8. Rohilla H. R., Singh H., Singh R. Evaluftion of rapeseed-mustard against mustard Lip aphid aphis erysimi (Kalt.). Agrochemicals and Cultivars. 1999. P. 4243.

9. Kostetska K., Osokina N., Gerasymchu H., Nakloka O. Objective organoleptic, structural-and-mechanical parameters of vegetables depending on their degree of ripeness. Agronomy Research. 2019. Vol. 17 (6). P. 2286-2294.

10. Osadcuks. V. \& Pecka, A. Electrical field based detection of fruits and vegetables for robotized horticulture. Agronomy Research. 2016. Vol. 14 (S1), 10881098.

11. Воробйова Н. В., Кухнюк О. В., Прудкий Р. І. Нанотехнології в овочівництві України. Science and Education a New Dimension. Natural and Technical Sciences. 2018. Vol. (21), № 179, C. 13-15.

12. Методика дослідної справи в овочівництві і баштанництві [Текст] / за ред. Г. Л. Бондаренка, К. І. Яковенка. 3-е вид. Харків: Основа, 2001. 369 с. 
13. Волкодав В. В. Спосіб державного сортування сільськогосподарських культур (картопля, овочі і баштанні культури). Київ, 2016. $94 \mathrm{c}$.

\section{References}

1. Ulianych, O. I., Alekseichuk, O. M. (2015). The use of natural products for the pre-sowing treatment of vegetable spinach seeds. Electronic Collection of Scientific Reports of the National University of Life and Environmental Sciences of Ukraine, 2015, no. 5 (54). http://nd.nubip.edu.ua/2015_5/index.html (in Ukrainian).

2. Ulianych, O. I, Alekseichuk, O. M., Prudkyi, R. Y., Dydenko, Y. A. (2015). Use of biological products for ecologically safe production of garden spinach and celery spinach. Scientific articles of the State Agrarian University of Moldova, 2015, vol. 42, pp. 225-227. (in Russian).

3. Bartolini, S., Ducci, E. (2017). Quality evaluation of local apple varieties: physicochemical and antioxidant proprieties at harvest and after cold storage. Agronomy Research, 2017, no. 15 (5), pp. 1866-1877. (in English).

4. Darby, K., Batte, M. T., Ernst, S., Roe, B. (2008). Decomposing local: A conjoint analysis of locally produced foods. Am. J. Agr. Econ, 2008, no. 90 (2), pp. 476-486. (in English).

5. Corbo, M. R., Nobile, M. A. D., Sinigaglia, M. (2006). A novel approach for calculation shelf life of minimally processed vegetables. International Journal of Food Microbiology, 2006, no. 106, pp. 69-73. (in English).

6. Bosland, P. W., Williams, P. H. (1988). Pathogenicity of geographic isolates of Fusarium oxysporum from crucifers on a differential set of crucifer seedlings. Phytopathol, 1988, no. 123, pp. 63-68. (in English).

7. Mansfeld, R. Vorlau figes verzeich nigland wirts chaftli chodergärtnerisch kultivierten Pflanzenarten. (Mit Ausschluss von Zierpflanzen). Die Kultur pflanze. Berlin, 1959. Beiheft 2. 
8. Rohilla, H. R., Singh, H., Singh, R. (1999). Evaluftion of rapeseedmustard against mustard Lip aphid aphis erysimi (Kalt.). Agrochemicals and Cultivars, 1999, pp. 42-43. (in English).

9. Kostetska, K., Osokina, N., Gerasymchuk, O., Nakloka, V. (2019). Objective organoleptic, structural-and-mechanical parameters of vegetables depending on their degree of ripeness. Agronomy Research, 2019, Vol. 17 (6), pp. 2286-2294. (in English).

10. Osadcuks, V., Pecka, A. (2016). Electrical field based detection of fruits and vegetables for robotized horticulture. Agronomy Research, 2016, Vol. 14 (S1), pp. 1088-1098. (in English).

11. Vorobiova, N. V., Kukhniuk, O. V., Prudkyi, R. I. (2018). Nanotechnology in vegetable growing in Ukraine. Science and Education a New Dimension. Natural and Technical Sciences, 2018, vol. (21), 179. pp. 13-15. (in Ukrainian).

12. Bondarenko, H. L., Yakovenko, K. I. (2001). Methodology of experimental work in vegetable and melon. Kharkiv: Osnova, 2001. 369 p. (in Ukrainian).

13. Volkodav, V. V. (2016). Method of state sorting of agricultural crops (potatoes, vegetables and melons), 2016. Kyiv. 94 p. (in Ukrainian).

\section{Аннотация}

\section{Ульянич Е., Осокина Н., Костецкая Е., Кухнюк О., Шевчук К.}

\section{Управление качеством овощей с использованием нано препаратов}

Проанализировано влияние элементов агротехнологии на продуктивность шпината. Абсорбенты в засушливых условиях современного климата способствуют увеличению урожайности шпината и получению высококачественной продукщии. Использование абсорбентов из Максимарина для выращивания шпината способствовало его более быстрому прорастанию, 
ускорению роста и развития растений, а также увеличению урожайности товарной продукции на 2,0-6,1 m/га и улучшению химического состава.

В условиях Лесостепи Украинь проведеньл экспериментальные исследования, которые позволили решить отдельные вопросы технологии выращуивания шпината огородного и доказано, что абсорбенты в засушливых условиях современного климата эффективны для повышения его урожайности, при которых не ухудшается качество продукиии.

На основе проведенных исследований разработаны и рекомендовань сельскохозяйственным товаропроизводителям промыиленного, частного и приусадебного сектора выращуивать отечественные раннеспелье сорта шпината огородного Красавец Полесья и Малахит. Абсорбенты в засушливых условиях современного климата способствуют повышению урожайности шпината огородного и получению высокого качества продукции.

Ключевые слова: ипинат, сорт, абсорбент, товарная продукция, урожайность, показатели качества.

\section{Annotation}

\section{Ulianych O., Osokina N., Kostetska K., Kuhnyuk O., Shevchuk K. Quality management of vegetables with the application of nano preparations}

The analysis of the elements of prickly seeded spinach growing technology was made. Absorbents in arid conditions of modern climate contribute to increase of the prickly seeded spinach and receiving of high-quality production._The use of absorbents from Maximarin for growing spinach contributed to its faster germination, increased plant growth and development, and resulted in an increase in yields of commodity products by 2.0-6.1 t/ha and an increase in chemical composition.

In the conditions of the Forest-Steppe of Ukraine, experimental researches were carried out, which allowed to solve certain questions of technology of growing of spinach of vegetable garden and it is proved that absorbents in arid conditions of 
modern climate are effective for increase of productivity of vegetable spinach, at which quality of production is not worsened.

Based on the conducted research, it is developed and recommended for agricultural producers of industrial, private and personal sector to grow domestic early ripening varieties of spinach of the city Krasen Polissya and Malachite. Absorbents in arid conditions of modern climate contribute to increase of spinach of vegetable garden and reception of high quality of production.

Key words: spinach, variety, absorbent, commodity products, yield, quality indices.

УДК 633.63: 631. 531.12

DOI 10.31395/2415-8240-2020-96-1-193-205

\section{БІОЛОГІЧНИЙ СТАН СПОКОЮ НАСІННЯ ПРОСА ПРУТОПОДІБНОГО (РАNICUM VIRGATUM L.) ТА СПОСІБ ЙОГО ЗНИЖЕННЯ}

В. В. ДРИГА, кандидат сільськогосподарських наук Інститут біоенергетичних культур і цукрових буряків НААН України

Наведено результати дослідження ефективності скарифікаиії насіння проса прутоподібного з метою зниження біологічного стану його спокою залежно від сортових особливостей. Якість насіння залежала як від сортових особливостей, так $i$ від кількості видаленої оболонки насінини під час скарифікації. За скарифікації окремих партій насіння обох сортів енергія проростання $i$ схожість достовірно підвищувалися, а окремих, навіть зменшувалися.

Ключові слова: схожість, енергія проростання, режими скарифікаиії, сортові особливості, оболонка насіння 